Jurnal Care Vol .5, No.3,Tahun 2017

\title{
PENGETAHUAN DAN KETERAMPILAN IBU DALAM BERKOMUNIKASI MASALAH SEKSUALITAS DITINJAU DARI JENIS KELAMIN REMAJA
}

\author{
Rani Widiyanti Surya Atmaja \\ Poltekkes Tasikmalaya Prodi Kebidanan Cirebon \\ e-mail : rani.widiyanti.s@dosen.poltekkestasikmalaya.ac.id
}

\begin{abstract}
Communicating sexuality issues between mothers and their teenagers is one of the most important and significant effects in development of teenager's sexual attitudes and behavior. Previous studies showed that, communication between mothers and their teenagers is limited, especially with regard to sexual issues. There are some obstacles possibly causing this problem, such as lack of knowledge on sexuality and that of skill in communication. The purpose of this study was to determine the differences mother knowledge and skill in communicating sexuality issues based on the sex of teenagers. The study design was analytic survey with cross sectional approach. The samples were 92 mothers of 14 years old students from SMP Negeri 1 Mundu, taken by purposive sampling. The study was conducted in July 2015 by using primary data questionnaires on sexuality issues and communication skill of observation sheet. Result showed that the majority mother in elementary education is 65,2\% and 76,1\% as housewife. The average is 38 years old and has 3 children. The average score of knowledge was only 58-60\% answered correctly and skill just 52-65\%. Based SPSS 17 analysis using Independent T-test showed mother knowledge there is no significant difference between teenager girls and men is Pvalue $=0.421$, but mother skills to communicating sexuality issues there was significant difference between teenager girls and men is Pvalue $=0,000$. The differences are in the ability to understand themselves, communicate thoughts and feelings clearly, and receive each other and provide support.
\end{abstract}

Key words: communication, mother, teenager, sexual issues.

\begin{abstract}
ABSTRAK
Komunikasi masalah seksualitas antara ibu dengan remaja memberikan pengaruh yang paling penting dan signifikan dalam perkembangan sikap dan perilaku seksual remaja. Studi sebelumnya menunjukkan bahwa terkait komunikasi antara ibu dan remaja masih kurang, khususnya yang berkaitan dengan masalah seksualitas. Beberapa kendala yang mungkin menyebabkan masalah ini, seperti kurangnya pengetahuan tentang seksualitas dan keterampilan dalam komunikasi. Tujuan dari penelitian ini adalah untuk mengetahui perbedaan pengetahuan dan keterampilan ibu dalam mengkomunikasikan masalah seksualitas berdasarkan jenis kelamin remaja. Rancangan penelitian survey analitik dengan pendekatan cross sectional. Sampel adalah 92 ibu dari siswa SMP Negeri 1 Mundu yang berusia 14 tahun, diambil secara purposive sampling. Penelitian menggunakan data primer kuesioner pengetahuan tentang masalah seksualitas dan keterampilan komunikasi dari lembar observasi. Hasil penelitian menunjukkan bahwa mayoritas ibu pada pendidikan dasar sebesar $65,2 \%$ dan 76,1\% sebagai ibu rumah tangga. Rata-rata berusia 38 tahun dan memiliki 3 orang anak. Rata-rata skor pengetahuan ibu hanya 58-60\% dan keterampilan komunikasi hanya 52-65\%. Berdasarkan analisis SPSS 17 dengan menggunakan Independent T-test menunjukkan
\end{abstract}


pengetahuan masalah seksualitas ibu tidak ada perbedaan signifikan berdasarkan jenis kelamin remajanya yaitu dengan pvalue $=0,421$, namun keterampilan ibu dalam mengkomunikasikan masalah seksualitas terdapat perbedaan yang signifikan antara remaja putri dengan pria yaitu pvalue $=0,000$. Perbedaan tersebut terdapat pada kemampuan untuk memahami diri sendiri, mengkomunikasikan pikiran dan perasaan dengan jelas dan saling menerima serta memberikan dukungan.

Kata Kunci: ibu, komunikasi, ketrampilan,masalah seksual

\section{PENDAHULUAN}

Cara komunikasi seseorang dengan orang lain berbeda apalagi dengan remaja. Jumlah remaja $1 / 4$ jumlah penduduk di dunia. Di Indonesia 26,67 jiwa (26,6\%) adalah remaja. (BKKBN,2011). Menurut Batubara (2010:25) remaja saat ini mengalami pubertas yang lebih dini dan penundaan perkawinan namun dihadapkan dengan informasi seksualitas yang mudah diperoleh sehingga menimbulkan masalah berkaitan dengan perilaku seksual. Pada remaja laki-laki lebih banyak melakukan perilaku seksual berat dibandingkan dengan perempuan. Menurut Tukirman (2010:260) bagi remaja laki-laki, melakukan hubungan seksual tidak akan merugikan laki-laki. Salah satu upaya yang dapat mempengaruhi sikap dan perilaku seksual remaja adalah komunikasi masalah seksualitas ibu dengan remaja. Hasil penelitian Mertia (2008:22) menunjukkan sumbangan efektif pengetahuan seksualitas dan komunikasi orangtua dan anak dengan perilaku seks bebas adalah 35,1\%.
Komunikasi yang lebih baik antara ibu dengan anak memiliki hubungan positif dengan usia pertama kali pacaran dan konsistensi penggunaan kontrasepsi. Akan tetapi menurut Ayalew (2014:6), pada kenyataannya hanya $5 \quad \%$ informasi seksualitas diperoleh dari orangtua. Komunikasi ibu dengan remaja termasuk dalam komunikasi interpersonal. Hasil penelitian menunjukkan bahwa orangtua akan membahas seksualitas dengan remaja jika mereka percaya diri dalam pengetahuan. Selain itu pendekatan dan cara orangtua ketika berbicara dengan remaja mengenai masalah seksualitas memiliki pengaruh besar pada remaja.

Cirebon merupakan salah satu kota yang lebih dari 900 anak muda kisaran usia 13-19 tahun diketahui mempunyai perilaku seks yang berisiko (Pikiran rakyat, 2013). Salah satu kecamatan dengan kenaikan jumlah PUS dari istri yang berumur $<20$ tahun adalah di Kecamatan Mundu. Penyebab terjadi pernikahan usia 
$<20$ tahun adalah telah hamil di luar nikah Oleh karena itu penelitian ini dilaksanakan di SMP Negeri 1 Mundu guna mengetahui perbedaan pengetahuan dan keterampilan komunikasi masalah seksualitas ibu dengan remajanya antara laki-laki dengan perempuan.

\section{METODE PENELITIAN}

Penelitian ini adalah penelitian survey analitik dengan rancangan cross sectional yang dilakukan pada 92 ibu dari siswa kelas 8 SMP Negeri I Mundu yang memenuhi kriteria inklusi antara lain ibu yang tinggal serumah dengan remajanya di kecamatan Mundu dan dapat membaca menulis. Sedangkan kriteria eksklusi penelitian ini adalah tidak bersedia ikut dalam penelitian dan berada diluar Kecamatan Mundu. Penelitian dilaksanakan di SMP Negeri I Mundu dengan menggunakan data primer dan alat ukur berupa kuesioner pengetahuan seksualitas yang telah dilakukan uji validitas dan reliabilitas dan lembar observasi keterampilan komunikasi seksualitas ibu. Analisis data menggunakan uji Independent T-test. Kemaknaan hasil uji ditentukan berdasarkan nilai $\mathrm{p}<0.05$.

\section{HASIL}

Sebanyak 92 menjadi subjek penelitian dengan karakteristik subjek yang diamati umur, paritas, pendidikan, pekerjaan dan jenis kelamin anak.

Tabel 1. Karakteristik Subjek

\begin{tabular}{|c|c|c|c|}
\hline No & Karakteristik & $\mathrm{f}$ & $\%$ \\
\hline \multirow[t]{3}{*}{1} & $\begin{array}{l}\text { Jenis Kelamin } \\
\text { Anak }\end{array}$ & & \\
\hline & a. anak laki-laki & 48 & 52.2 \\
\hline & $\begin{array}{l}\text { b. anak } \\
\text { perempuan }\end{array}$ & 44 & 47.8 \\
\hline \multirow[t]{5}{*}{2} & Pendidikan & & \\
\hline & a. Tidak Sekolah & 9 & 9.8 \\
\hline & b. SD & 60 & 65.2 \\
\hline & c. SMP & 18 & 19.6 \\
\hline & d. SMA & 5 & 5.4 \\
\hline \multirow[t]{5}{*}{3} & Pekerjaan & & \\
\hline & a. IRT & 70 & 76.1 \\
\hline & b. Buruh & 7 & 7.6 \\
\hline & c. Peg. swasta & 6 & 6.5 \\
\hline & d. Wiraswasta & 9 & 9.8 \\
\hline \multirow[t]{3}{*}{4} & Umur (tahun) & & \\
\hline & Mean & 38.86 & \\
\hline & Rentang & $30-58$ & \\
\hline \multirow[t]{3}{*}{5} & Paritas (anak) & & \\
\hline & Mean & 3.09 & \\
\hline & Rentang & $1-9$ & \\
\hline
\end{tabular}

Sumber : data primer biodata kuesioner 
Tabel 2 Distribusi Rata-rata Pengetahuan Seksualitas Ibu Menurut Jenis Kelamin Remaja.

\begin{tabular}{lccrrc}
\hline Jenis kelamin & Mean & \multicolumn{1}{l}{ SD } & \multicolumn{1}{l}{ SE } & P value & \multicolumn{1}{l}{ N } \\
\hline Laki-laki & 60 & 9.478 & 1.368 & 0.421 & 48 \\
Perempuan & 58.41 & 9.387 & 1.415 & & 44 \\
\hline
\end{tabular}

Sumber: Data kuesioner pengetabuan diolah dengan SPSS 17 uji Independent T-tes

Berdasarkan Tabel 1 dapat dilihat persentase anak laki-laki dan perempuan hampir sama. Umur ibu berada pada rentang 30-58 tahun (dewasa-lansia) dan rata-rata 38.86 tahun yaitu pada usia dewasa. Tingkat pendidikan ibu sebagian besar memiliki tingkat pendidikan rendah yaitu Sekolah Dasar (SD). Mayoritas ibu tidak bekerja yaitu menjadi Ibu Rumah Tangga (IRT). Jumlah anak berada pada rentang 1-9 dan rata-rata 3 anak.
Berdasar Tabel 2 diketahui rata-rata skor pengetahuan ibu yang memiliki anak lakilaki adalah 60 dengan standar deviasi 9.478, sedangkan untuk ibu yang memiliki anak perempuan rata-rata skor pengetahuannya adalah 58.41 dengan standar deviasi 9.387. Hasil uji statistik didapat nilai $\mathrm{p}=0.421$, berarti pada alpha $5 \%$ terlihat tidak ada perbedaan yang signifikan rata-rata skor pengetahuan seksualitas antara yang memiliki anak lakilaki dengan perempuan

Tabel 3 Distribusi Rata-rata Keterampilan Komunikasi Masalah Seksualitas Ibu Dengan Remaja Menurut Jenis Kelamin Remaja

\begin{tabular}{lccccc}
\hline Jenis kelamin & Mean & SD & SE & P value & N \\
\hline Laki-laki & 52.17 & 16.908 & 2.441 & 0.000 & 48 \\
Perempuan & 65.06 & 13.752 & 2.073 & & 44
\end{tabular}

Sumber: Data lembar observasi keterampilan diolah dengan SPSS 17 uji Independent T-test

Tabel 3 menunjukkan rata-rata skor keterampilan ibu yang memiliki anak lakilaki adalah 52.17 dengan standar deviasi 16.908, sedangkan untuk ibu yang memiliki anak perempuan rata-rata skor keterampilannya adalah 65.06 dengan standar deviasi 13.752. Hasil uji statistik didapat nilai $\mathrm{p}=0.000$, berarti pada alpha $5 \%$ terlihat ada perbedan yang signifikan keterampilan komunikasi masalah seksualitas ibu dengan remaja antara yang memiliki anak laki-laki dengan perempuan. 
Tabel 4. Distribusi Aspek Keterampilan Komunikasi Masalah Seksualitas Ibu Dengan Remaja Menurut Jenis Kelamin Remaja

\begin{tabular}{llccccc}
\hline \multicolumn{1}{c}{ Aspek Keterampilan } & Jenis kelamin & Mean & SD & SE & P value & N \\
\hline Mampu memahami diri & Laki-laki & 5.15 & 1.924 & 0.278 & 0.005 & 48 \\
orangtua dan remaja & Perempuan & 6.25 & 1.713 & 0.258 & & 44 \\
& Laki-laki & 5.52 & 1.913 & 0.276 & 0.000 & 48 \\
Mampu & Perempuan & 6.89 & 1.588 & 0.239 & & 44 \\
mengkomunikasikan & & & & & \\
fikiran dan perasaan & & & & & & \\
secara tepat dan jelas & & 1.58 & 1.108 & 0.160 & 0.008 & 48 \\
mampu saling menerima & Laki-laki & 2.16 & 0.914 & 0.138 & & 44 \\
dan memberi dukungan & Perempuan & & & & & 48 \\
Mampu memecahkan & Laki-laki & 0.27 & 0.536 & 0.077 & 0.668 & 44 \\
konflik dan masalah & Perempuan & 0.32 & 0.518 & 0.078 & & 44 \\
& & & & & &
\end{tabular}

Sumber: Data aspek observasi keterampilan diolah dengan SPSS 17 uji Independent T-test

Berdasar Tabel 4 didapatkan nilai $\mathrm{p}=0.005$ pada aspek mampu memahami diri orangtua dan remaja, $\mathrm{p}=0.000$ pada aspek mampu mengkomunikasikan fikiran dan perasaan secara tepat dan jelas, $\mathrm{p}=0.008$ pada aspek mampu saling menerima dan memberi dukungan, berarti pada alpha $5 \%$ terlihat ada perbedan yang signifikan rata-rata skor apsek mampu memahami diri orangtua dan remaja, aspek mampu mengkomunikasikan fikiran dan perasaan secara tepat dan jelas serta aspek mampu saling menerima dan memberi dukungan antara yang memiliki anak laki-laki dengan perempuan.

\section{PEMBAHASAN}

Pengetahuan seksualitas adalah upaya memberikan pengetahuan tentang perubahan biologis dan psikososial akibat pertumbuhan dan perkembangan manusia. Penelitian yang dilakukan Agustina (2012:55) sebanyak 56,7\% orangtua dengan pengetahuan seksualitas rendah. Pengukuran pengetahuan seksualitas pada penelitian tersebut berdasarkan kategori yang dibuat Arikunto bahwa kategori baik $>75 \%$, cukup $60-70 \%$ dan kurang $<60 \%$. Berdasarkan Tabel 2, skor rata-rata pengetahuan seksualitas ibu dari remaja laki-laki yaitu 60 sedangkan perempuan hanya 58,.41 sehingga jika dikategorikan termasuk kurang. Pengetahuan seseorang 
dipengaruhi oleh beberapa faktor diantaranya pendidikan, pekerjaan, pengalaman dan umur.

Hasil penelitian pada Tabel 1 menunjukkan mayoritas responden tingkat pendidikan SD, ibu tidak bekerja, jumlah anak 3 dan umur ibu rata-rata 38,5 tahun. Tingkat pendidikan mempengaruhi persepsi seseorang untuk lebih menerima ide sehingga semakin tinggi pendidikan maka pengetahuan semakin meningkat. Pekerjaan adalah kegiatan yang dilakukan sehari-hari, semakin sesuai dengan kegiatan yang dilakukan maka semakin tinggi tingkat kepuasannya sehingga keinginan untuk mencari tahu informasi meningkat. Pengalaman juga dapat mengembangkan kemampuan dalam pengambilan keputusan sebagai hasil manifestasi nalar dari masalah nyata sehingga semakin banyak mengasuh anak maka kemampuan berfikir meningkat. Umur diatas 40 tahun terjadi penurunan fungsi alat indra yang akan menurunkan daya ingat sehingga semakin tua umur ibu maka kemampuan mengingat informasi berkurang. Berdasarkan teori tersebut dan karakteristik responden penelitian maka terdapat kesesuaian antara pendidikan rendah, ibu tidak bekerja dan pengalaman mengurusi 3 anak dengan rendahnya skor pengetahuan walaupun pada umur ibu seharusnya dapat menerima dan mengingat informasi. Hal ini dapat dikarenakan informasi mengenai seksualitas remaja yang ibu dapatkan kurang sedangkan sumber informasi lain yang diterima ibu mengenai seksualitas remaja tidak diteliti dalam penelitian ini. Sumber informasi seputar seksualitas remaja yang ibu dapatkan selama ini hanya dari pengajian atau televisi berdasarkan penelitian sebelumnya yang dilakukan Erni (2013:70).

Pada penelitian sebelumnya yang dilakukan Aryani (2015:4) bahwa orangtua dengan pendidikan rendah memberikan pendidikan seksualitas dengan tidak sengaja karena tidak memahami tentang makna seks sehingga informasi yang diberikan seputar seksualitas disamarkan dan tidak jelas akibatnya anak masih mencari informasi dari orang atau media lain. Hasil penelitian bahwa skor pengetahuan ibu dari remaja laki-laki sedikit lebih tinggi daripada ibu dari remaja perempuan hal ini dikarenakan ibu mendapatkan pengalaman perkembangan seksualitas yang berbeda diluar yang dialami pada dirinya namun tidak banyak meningkatkan pengetahuan ibu seputar seksualitas. Pada uji statistik didapatkan tidak ada perbedaan yang signifikan pengetahuan seksualitas ibu antara yang 
memiliki anak laki-laki dengan anak perempuan.

Berdasarkan Tabel 3 rata-rata skor keterampilan ibu yang memiliki anak lakilaki adalah 52.17, sedangkan untuk ibu yang memiliki anak perempuan rata-rata skor keterampilannya adalah 65.06. Ibu yang memiliki anak perempuan lebih tinggi memiliki skor keterampilan komunikasi masalah seksualitas dibanding yang memiliki anak laki-laki padahal pengetahuan seksual ibu lebih rendah dibandingkan yang memiliki anak laki-laki. Menurut Wiendijarti (2011:279) hal ini disebabkan ibu masih memberikan penjelasan dan pendampingan pada anak perempuan ketika memasuki masa menstruasi tetapi pada remaja laki-laki dibiarkan mencari tahu sendiri apa yang terjadi saat mulai mimpi basah. Dalam penelitian ini anak laki-laki cenderung pasif saat berbicara seksualitas dengan ibunya sehingga ibu tidak mengetahui perubahan yang terjadi pada anak.Selain itu senada dengan penelitian Ernawati (2015) bahwa baik anak laki-laki maupun anak perempuan memilih ibu sebagai sumber informasi mengenai seksualitas namun porsi perempuan mendapatkan informasi seksualitas lebih banyak. Hal yang dibicarakan terbatas pada cara menjaga organ reproduksi dan menstruasi.
Keterampilan adalah kemampuan melakukan secara baik yang timbul berkat pelatihan atau praktek sehari-hari Ratarata keterampilan komunikasi masalah seksualitas ibu dalam penelitian ini jika berdasarkan skala Arikunto berada di rendah hingga sedang. Komunikasi ibu dan remaja yang masih rendah dikarenakan remaja memandang ibu tidak memiliki cukup keahlian tentang topik yang berkaitan dengan seksualitas, keterbukaan membahas suatu masalah dan ibu cenderung menghakimi. Berdasarkan penelitian Yulianto (2010:50) gambaran pihak yang diajak berbicara masalah seksualitas pada anak SMP di Depok adalah teman, orangtua, saudara, guru dan pacar. Orangtua hanya berada pada urutan kedua setelah teman sehingga memungkinkan kurang terasahnya keterampilan komunikasi orangtua mengenai seksualitas. Padahal dengan membicarakan topik seksualitas dengan orangtua maka remaja cenderung memiliki sikap menolak hubungan seksual pranikah. Selain itu keterampilan merupakan aplikasi dari pengetahuan sedangkan pada penelitian ini responden memiliki pengetahuan seksualitas yang rendah sehingga berpengaruh pada rendah keterampilan komunikasi seksualitas ibu dengan remaja. Oleh karena itu orang tua dituntut memiliki pengetahuan luas dan 
teknik penyampaian yang baik mengenai seksualitas.

Komunikasi yang terjalin antara ibu dengan remaja menurut Wiendijarti merupakan komunikasi yang jujur, terdapat empati dan dukungan serta kesamaan persepsi sesuai dengan teori prinsip dasar komunikasi interpersonal. Pada dasarnya anak menginginkan untuk selalu diajak berdiskusi dan berpendapat yang didengarkan oleh ibu. Anak juga ingin berbicara dari hati kehati dengan suasana santai tanpa instruksi dari ibu. Hal ini dapat terlaksana jika persepsi ibu berubah seiring semakin dininya fertilisasi remaja dan berubah harapan masyarakat tentang remaja berkaitan dengan kematangan organ reproduksinya. Remaja memiliki harapan setelah mengalami kematangan organ reproduksi orangtua tidak menganggap mereka sebagai anak kecil. Sejalan dengan penelitian yang dilakukan Permana(2014:100) bahwa ibu memiliki pola hubungan yang yang lebih akrab pada anaknya baik laki-laki maupun perempuan dikarenakan lebih sabar, sering dirumah, lebih memahami dan mudah diajak bicara dibandingkan ayahnya

Pada uji statistik terdapat perbedaan yang signifikan keterampilan komunikasi masalah seksualitas ibu dengan remaja antara yang memiliki anak laki-laki dengan perempuan. Perbedaan tersebut pada aspek mampu memahami diri orangtua dan remaja. Adanya kendala perbedaan fisik yang mengakibatkan berhentinya komunikasi ketika menyangkut hal yang dianggap sangat pribadi. Selain itu aspek memahami diri dimulai dengan saling membuka diri.Menurut Sugiyatno (2015) membuka diri diawali dengan mengetahui tentang diri sendiri, kemampuan tersebut tergantung seberapa besar umpan balik orang lain. Sebelum seseorang mampu memberikan umpan balik, sikap terbuka terhadap masukan harus dimiliki. Salah satu cara sikap terbuka terhadap masukan yaitu berpikir positif. Namun pada ibu yang memiliki anak laki-laki masih beranggapan bahwa remaja susah diatur, pemberontak dan cara terbaik adalah dengan membiarkan sesuai dengan kemauannya. Hal ini sejalan dengan penelitian Payanti (2012:47) bahwa remaja laki-laki memiliki persepsi bahwa mereka tidak dibekali penjelasan seksualitas sejak dini karena risiko yang ditanggung laki-laki lebih kecil dibanding perempuan akibat penyimpangan seksual, hal ini yang menjadikan remaja laki-laki lebih permisif.

Ibu harus memiliki pandangan positif terutama pada remaja laki-laki yang cenderung permisif dan memahami 
karakteristik perkembangan seksual antara laki-laki dan perempuan yang berbeda karena dipengaruhi oleh aspek biologis, psikologis dan sosiologis. Ibu harus dapat menerima dan mengakui perasaan serta tidak menyangkal atau menyembunyikan perasaan terutama dengan remaja laki-laki. Mengenal kemampuan dan kelemahan yang dimiliki ibu serta perasaan dan nilai mengenai seksualitas merupakan upaya untuk membuka diri. Selain itu mampu mendengarkan yang disampaikan remaja serta memahami perasaan dengan memperhatikan bahasa tubuh.Aspek selanjutnya yang terdapat perbedaan adalah mampu menginformasikan fikiran dan perasaan secara tepat dan jelas. Aspek tersebut meliputi volume suara, intonasi dan kecepatan suara, bahasa dapat dipahami dan tidak menyudutkan, jelas menangkap dan memahami pertanyaan, bicara spontan, jawaban berisi fakta dan mengkomunikasikan pesan nilai serta moral. Selain itu bahasa yang digunakan harus diperhatikan. Ibu sangat berhati-hati menggunakan kata dan bahasa karena dikhawatirkan anak salah mengartikan informasi yang diberikan. Sebagian besar ibu menggunakan bahasa Cirebon dalam berkomunikasi.

Penggunaan kata yang jelas tidak disamarkan dengan simbol yang dapat dipahami oleh remaja sehingga mencegah kesalahan mengartikan makna seputar seksualitas. Kecepatan bicara harus diatur agar tidak terlalu cepat maupun lambat sehingga remaja dapat menangkap informasi seputar seksualitas. Hal lain yang perlu diperhatikan adalah intonasi suara karena akan mempengaruhi arti pesan secara dramatik yang memiliki arti berbeda bila diucapkan dengan intonasi berbeda. Volume suara memadai diartikan dapat jelas terdengar oleh lawan bicara. Beberapa responden masih canggung berkomunikasi terutama dengan anak lakilaki sehingga informasi mengenai seksualitas masih ditutup-tutupi.Aspek yang berbeda lainnya adalah kemampuan saling menerima dan memberi dukungan yang meliputi menikmati interaksi, bereaksi menyenangkan adanya respon senyuman, anggukan atau sentuhan. Ibu memulai pembicaraan dengan hal-hal yang ringan seperti menanyakan kegiatan disekolah, kemudian pembicaraan berangsur-angsur beralih dengan topik seksualitas sesuai dengan kasus yang diberikan. Sesekali ibu merespon dengan senyuman dan anggukan saat remaja mengomentari pesan yang disampaikan. Pada usia remaja terutama anak laki-laki sangat malu jika mendapat sentuhan dari ibunya sehingga interaksi pada anak lakilaki lebih pasif padahal kemampuan 
menikmati interaksi dan bereaksi menyenangkan pada ibu akan membangun komunikasi yang initim sehingga menumbuhkan kepercayaan pada anak laki-laki untuk dapat menceritakan kehidupan pribadinya terutama seputar seksualitas

\section{KESIMPULAN}

1. Pengetahuan seksualitas ibu yang memiliki anak laki-laki maupun perempuan dalam kategori rendah.

2. Keterampilan komunikasi masalah seksualitas ibu dengan remaja lakilaki maupun perempuan dikategori rendah hingga sedang

3. Tidak ada perbedaan yang signifikan pengetahuan seksualitas ibu antara yang memiliki remaja laki-laki dengan remaja perempuan

4. Ada perbedaan yang signifikan keterampilan komunikasi masalah seksualitas antara yang memiliki remaja laki-laki dengan remaja perempuan

5. Aspek yang berbeda pada keterampilan komunikasi masalah seksualitas antara yang memiliki remaja laki-laki dengan perempuan adalah mampu memahami diri orangtua dan remaja, aspek mampu mengkomunikasikan fikiran dan perasaan secara tepat dan jelas serta aspek mampu saling menerima dan memberi dukungan.

Direkomendasikan untuk perlunya melakukan penelitian lebih lanjut dengan menambahkan variabel dan metode berbeda serta dapat mengkaitkannya dengan perilaku seksual pranikah remaja.

\section{REFERENSI}

Agustina E, Hapsari R.W. (2012). Hubungan Antara Pengetahuan Keluarga tentang Pendidikan Seks dengan Perilaku Keluarga Dalam Pemberian Pendidikan Seks Pada Remaja. J AKP 5:5460.

Aryani D. (2015). Komunikasi Antar Pribadi Orangtua dan Anak Pada Masa Awal Pubertas tentang Pendidikan Seks di Kelurahan Mogolaing Kota Kotamobagu Barat. Journal Acta Diurna. Diperoleh dari : www.ejurnal.com/2015/08/komunikas i-antarpribadi-orangtuadanhtml?m $=1$

Ayalew M, Mengistie B, Semahegn A.(2014). Adolescent - Parent Communication On Sexual And Reproductive Health Issues Among High School Students in Dire Dawa Eastern Ethiopia: A 
Cross Sectional Study. $R H$ 11(77):1-8.

Batubara JR. (2010). Adolescent

Development (Perkembangan remaja). Sari Pediatri 12 (1):21-32.

Ernawati H. (2015). Pemanfaatan orangtua sebagai sumber informasi kesehatan reproduksi remaja di daerah pedesaan. Prosiding Seminar Nasional. Diperoleh dari : http://eprints.umpo.ac.id/1631 L

Erni. (2013). Pendidikan Seks pada Remaja. J Health Quality 3(2): 69140.

Mertia EN, Hidayat T, Yuliadi I. (2011). Hubungan antara pengetahuan seksualitas dan kualitas komunikasi orangtua dan anak dengan perilaku seks bebas pada remaja siswa-siswi MAN Gondangrejo Karanganyar. Wacana J Psyech 1-28.

Payanti N. (2012). Hubungan Pemberian Pendidikan Seks Oleh Orangtua dengan Perilaku Seks Pranikah Remaja. J Say 8(1): 41-51

Sugiyatno. (2015). Membuka Diri Dalam Interaksi..

http://staff.uny.ac.id.UNY.

Wiendijarti I. (2011). Komunikasi Interpersonal Orangtua dan Anak dalam Pendidikan Seksual. J Ilmu Komunikasi 9(3): 274-292. Yulianto. (2010). Gambaran Sikap Siswa SMP Terhadap Perilaku Seksual Pranikah. J Psych 8(2); 46-58 